\title{
Association of 3 CDC opioid prescription guidelines for chronic pain and 2 payer pharmacy coverage changes on opioid initiation practices
}

Adeniyi T Togun, MD, MPH, MS, PhD; Pinar Karaca-Mandic, PhD; Rebecca Wurtz, MD, MPH; Molly M Jeffery, PhD; and Timothy Beebe, MA, PhD

\section{What is already known about this subject}

- The CDC guidelines were recommended for primary care providers.

- The CDC guidelines were not associated with any change in the rate of prescription of extendedrelease opioids (both first-time and maintenance prescriptions as a composite) compared with immediate-release opioids.

- The CDC guidelines were associated with a reduction in the rate of (both first-time and maintenance prescriptions as a composite) opioid prescription doses of at least 90MME (morphine milligram equivalent) per day.

- The CDC guidelines were associated with a reduction in the rate of all opioid prescriptions (both first-time and maintenance prescriptions as a composite) with benzodiazepine overlap.

\section{What this study adds}

- Some specialist providers adopted the CDC guidelines.

- Among different provider specialties, the CDC guidelines were associated with reduction in first-time opioid prescriptions at a dose of at least 50 MME per day, and first-time opioid prescription with benzodiazepine overlap, but not first-time extendedrelease opioid prescriptions.

- Among different provider specialties, payer pharmacy coverage changes were associated with a reduction in first-time extended-release opioid prescriptions and first-time opioid prescriptions at a dose of at least 50 MME per day.

- Payer pharmacy coverage changes were associated with reducing first-time extended-release opioid prescription, while the $C D C$ guidelines were not.

- Using a nationally representative claims dataset, the study evaluates three of the CDC guidelines and two payer pharmacy coverage changes on opioid initiation in patients for whom they were recommended: noncancer and nonpalliative care patients with known chronic pain conditions.

\section{Author affiliations}

Adeniyi T Togun, MD, MPH, MS, PhD, Department of Health Services Research, School of Public Health, University of Minnesota Twin Cities, Minneapolis. Rebecca Wurtz, MD, MPH, and Timothy Beebe, MA, PhD, Division of Health Policy and Management, School of Public Health, University of Minnesota Twin Cities, Minneapolis. Pinar Karaca-Mandic, PhD, OptumLabs Visiting Fellow, Carlson School of Management, Department of Finance, University of Minnesota, Minneapolis, and National Bureau of Economic Research, Cambridge, MA. Molly M Jeffery, PhD, Department of Health Services Research, Mayo Clinic, Rochester, MN.

AUTHOR CORRESPONDENCE: Adeniyi T Togun, 612.532.3071; togun001@umn.edu

J Manag Care Spec Pharm 2021;27(10):1352-64

Copyright $@ 2021$, Academy of Managed Care Pharmacy. All rights reserved.

with changes in opioid initiation patterns is unknown.

OBJECTIVE: To assess the association between 3 of the 2016 CDC guidelines and 2 subsequent payer pharmacy coverage new guidelines for primary care providers on opioid prescribing for chronic pain. Payer coverage changes were also implemented to help modify opioid prescribing behavior Whether these initiatives were associated

\section{ic, in March of 2016, the Centers for Disease \\ Control and Prevention (CDC) published \\ ABSTRACT \\ BACKGROUND: Due to the US opioid epidem-}


changes with changes in opioid initiation behavior across different provider specialties.

METHODS: We conducted a real-world evidence study using claims data from OptumLabs Data Warehouse between January of 2014 and December of 2018. Subjects were continuously enrolled opioid naive patients, aged at least 18 years, who had at least 1 chronic pain diagnosis within 2 weeks before their first (first-time) opioid prescription. The study used multiple treatment period segmented regression analysis to evaluate the association, across different provider specialties, between the CDC guideline release and the payer pharmacy coverage changes with immediate change in level and overall change in the rate of first-time extended-release opioid prescriptions, firsttime opioid prescriptions at doses of at least $50 \mathrm{MME}$ (morphine milligram equivalent) per day, and first-time opioid prescriptions with overlapping benzodiazepine prescription.

RESULTS: The CDC guidelines were not associated with any change in the rate of first-time prescriptions of extended-release opioids. However, a January 2017 payer pharmacy coverage change was associated with a reduction over time in first-time extended-release opioid prescription rates by 22.15 in every 100,000 prescriptions $(\mathrm{Cl}=-40.04$ to $-2.92, P=0.013)$. The $C D C$ guidelines were associated with an immediate decline in level of first-time opioid prescription at doses of at least $50 \mathrm{MME}$ per day by 74.00 in every 10,000 prescriptions $(\mathrm{Cl}=-124.86$ to $-23.13, P=0.004)$ and an increased rate of decline over time by 13.64 in every 10,000 prescriptions $(\mathrm{Cl}=-17.07$ to $-10.21, P<0.001)$. These associations varied across provider types and specialties. The March 2018, payer coverage change was associated with an immediate reduction in level of first-time opioid prescriptions at doses of at least 50 MME per day across all specialties and an increased reduction over time among surgeons. The CDC guidelines were associated, respectively, with a reduction in the rate of overlapping first-time opioid prescriptions with benzodiazepines among family medicine, internal medicine, surgeons, emergency medicine providers, and providers with unknown specialty by 6.11 , $5.10,2.89,11.43$, and 9.11 in every 10,000 prescriptions monthly $(\mathrm{Cl}=-9.48$ to $-2.73,-9.86$ to $-0.35,-5.40$ to $-0.38,-17.26$ to -5.61 and -11.96 to -6.25 , respectively, $P<0.001, P=0.035, P=0.024, P<0.001$ and $P<0.001)$.

CONCLUSIONS: Some specialist providers also adopted the CDC guidelines, and the response to the guidelines differed across various provider specialties. Some CDC guidelines were associated with a reduction in high-risk first-time opioid prescriptions. Payer pharmacy coverage changes reinforced the guidelines both in situations where the CDC guidelines did and did not show any association.

Drug overdose is the leading cause of death among people under age 50 in the United States. ${ }^{1}$ Of the 63,632 drug overdose fatalities in 2016, 66\% involved prescription or illicit opioids (such as heroin or synthetic fentanyl). ${ }^{2}$ During 2016, more than $40 \%$ of all US opioid overdose deaths involved a prescription opioid, ${ }^{3}$ and prescription opioid-related overdose deaths increased by $10.6 \%$ between 2015 and $2016 .{ }^{4}$

More than $20 \%$ of US adults reported experiencing chronic pain in 2016, and opioids were the second most prescribed analgesic for chronic pain (second only to NSAIDs), even more prescribed than Acetaminophen(third most commonly prescribed drug for chronic pain). ${ }^{5}$ While the prevalence of pain reported by Americans has not changed since the 1990s, opioid prescriptions for pain have increased. ${ }^{6,7}$ Opioids are prescribed by both specialist and primary care providers; the latter group accounts for about $50 \%$ of opioid prescriptions. ${ }^{8,9}$ Moreover, opioid prescriptions from primary care providers are associated with the greatest number of prescription opioid fatalities. ${ }^{10}$ In March 2016, the Centers for Disease Control and Prevention (CDC) released new guidelines to primary care providers on opioid prescription for chronic pain not associated with active cancer treatment, palliative care, or end-of-life care. ${ }^{11}$ As clinicians often adopt evidence-based recommendations from outside of their own areas of practice, ${ }^{12-15}$ specialists may also have adopted the CDC guideline and the degree of adoption is unknown. Hence, this study evaluates if and how three of the $12 \mathrm{CDC}$ guidelines are associated with changes in first-time opioid prescribing practices across multiple provider specialties:

- Guideline 4: "When starting opioid therapy for chronic pain, clinicians should prescribe immediate-release opioids instead of extended-release/long-acting (ER/LA) opioids." "11

- Guideline 5: "When opioids are started, clinicians should prescribe the lowest effective dosage. Clinicians should use caution when prescribing opioids at any dosage, should carefully reassess evidence of individual benefits and risks when considering increasing dosage to $\geq 50$ morphine milligram equivalents (MME)/day, and should avoid increasing dosage to $\geq 90 \mathrm{MME} /$ day or carefully justify a decision to titrate dosage to $\geq 90 \mathrm{MME} /$ day." ${ }^{\prime 11}$

- Guideline 8: "Clinicians should avoid prescribing opioid pain medication and benzodiazepines concurrently whenever possible." ${ }^{\prime 11}$

Each of these guidelines was intended to address a specific opioid-related risk. The first guideline, which discourages starting opioid prescription with extendedrelease opioids, is crucial because overdose risk is higher with extended-release opioids compared to immediaterelease opioids. ${ }^{16,17}$ The second guideline, which discourages starting opioid prescriptions at doses of at least $50 \mathrm{MME}$ per day, seeks to address the issue that opioid complications, such as overdose and death, increase at higher doses. ${ }^{17,18}$ In a national Veterans Administration (VA) study, $59 \%$ of fatal opioid overdoses occurred with dosages of 


\section{TABLE 1 Patient and Provider Characteristics on First-Time Opioid Prescription}

\begin{tabular}{|c|c|c|}
\hline \multirow[b]{2}{*}{ Age } & \multicolumn{2}{|c|}{$\mathbf{N}(\%) /$ Mean (SD) } \\
\hline & 57.68 & $(16.52)$ \\
\hline Mean number of commorbidities (elixhauser) & 1.79 & $(1.96)$ \\
\hline \multicolumn{3}{|l|}{ Gender } \\
\hline Female & 314,603 & $(57.10)$ \\
\hline Male & 236,366 & $(42.90)$ \\
\hline \multicolumn{3}{|l|}{ Insurance type } \\
\hline Commercial & 325,948 & $(59.16)$ \\
\hline Medicare & 225,021 & $(40.84)$ \\
\hline \multicolumn{3}{|l|}{ PCSA metropolitanism } \\
\hline Metropolitan & 457,934 & $(83.11)$ \\
\hline Nonmetropolitan & 93,035 & $(16.89)$ \\
\hline \multicolumn{3}{|l|}{ Census regions } \\
\hline South & 259,786 & $(47.15)$ \\
\hline Midwest & 157,502 & $(28.59)$ \\
\hline West & 77,191 & $(14.01)$ \\
\hline Northeast and others & 56,490 & $(10.25)$ \\
\hline \multicolumn{3}{|c|}{ All first-time opioid fills across provider specialties } \\
\hline Primary care provider type & 160,447 & $(29.12)$ \\
\hline Family practice specialty & 99,091 & $(17.98)$ \\
\hline Internal medicine specialty & 55,507 & $(10.07)$ \\
\hline OB/GYN and Pediatrics specialty & 5,849 & $(1.06)$ \\
\hline Specialist provider type & 233,308 & $(42.35)$ \\
\hline Emergency medicine specialists & 47,729 & $(8.66)$ \\
\hline Internal medicine subspecialists & 14,937 & $(2.71)$ \\
\hline
\end{tabular}

Cardiologist, pulmonologist, neurologist, critical care medicine, gastroenterologist, dermatologist, nephrologist, hematologist geriatrician, rheumatologist, endocrinologist, immunologist, allergist, addiction medicine and infectious disease specialist

\begin{tabular}{|c|c|}
\hline Surgery specialists & 148,205 \\
\hline \multicolumn{2}{|c|}{$\begin{array}{l}\text { Thoracic surgeon, colon and rectal surgeon, neurosurgeon, } \\
\text { urologist, orthopedic surgeon, oncologist, plastic surgeon, vascula } \\
\text { surgeon, general surgeon, hand surgeon and otolaryngologist } \\
\text { surgeon }\end{array}$} \\
\hline Other specialists & 22,437 \\
\hline \multicolumn{2}{|c|}{$\begin{array}{l}\text { Radiologist, rehabilitation medicine, nuclear medicine, } \\
\text { neuropathologist, pathologist, ophthalmologist, podiatrist MD an } \\
\text { psychiatrist }\end{array}$} \\
\hline \multicolumn{2}{|l|}{ Unknown provider type } \\
\hline Other, unknown specialty & $157,214 \quad(28.53)$ \\
\hline
\end{tabular}

more than 50 MME per day, and 33\% with dosages of more than 90 MME per day; among the cases that did not experience fatal overdose, $76 \%$ had dosages of less than $50 \mathrm{MME}$ per day and $88 \%$ had dosages of less than 90 MME per day. ${ }^{17}$ Finally, the third guideline, which discourages starting opioid prescription overlapping with benzodiazepines, is important because both benzodiazepines and opioids cause respiratory suppression, and when taken together, increase the risk of overdose deaths. ${ }^{17}$ Previous studies ${ }^{19,20}$ have assessed the association of these three CDC guidelines on continued provider opioid prescribing behavior, but this study focuses on opioid initiation practices and also evaluates the guidelines in different provider specialties (Table 1).

Following the release of these $\mathrm{CDC}$ guidelines, commercial health care payers also modified their opioid prescription pharmacy coverage in attempt to discourage prescriptions of high-risk opioids. ${ }^{16}$ In January 2017, a large health care payer modified its pharmacy coverage and recommended that when initiating opioids, providers should start with immediate-release/short-acting opioids rather than extended-release/long-acting opioids..$^{21,22}$ Further, they required prior authorization and provider attestation to start with long-acting opioids instead of immediaterelease opioids. ${ }^{21,22}$ In March 2018, the same payer also modified its pharmacy coverage to cap maximum daily opioid doses at $49 \mathrm{MME}$ or less for members new to opioid therapy (no prior opioid use in the last 120 days). ${ }^{23}$ Prior studies have assessed the association between the CDC guidelines and provider opioid prescribing behavior, ${ }^{19,20,24}$ but this study also evaluates the association between pharmacy coverage changes and specifically evaluates opioid initiation behavior across provider specialties. ${ }^{25}$ Overall, the study evaluates association of three $\mathrm{CDC}$ guidelines and two payer coverage changes with changes in first-time extended-release opioid prescription, first-time opioid prescription at doses of at least 50 MME per day, and first-time opioid prescription with benzodiazepine overlap.

\section{Methods}

\section{STUDY POPULATION}

We identified first-time (index) opioid prescription fills between January 1, 2014 and December 31, 2018 from OptumLabs Data Warehouse (OLDW), ${ }^{26}$ a deidentified administrative medical and pharmacy claims database of commercial and Medicare Advantage (MA) enrollees. OLDW contains longitudinal health information on enrollees and patients, representing a diverse mix of ages, ethnicities, and geographical regions across the United States. 


\section{FIGURE 1 Three Time Period Diagram}

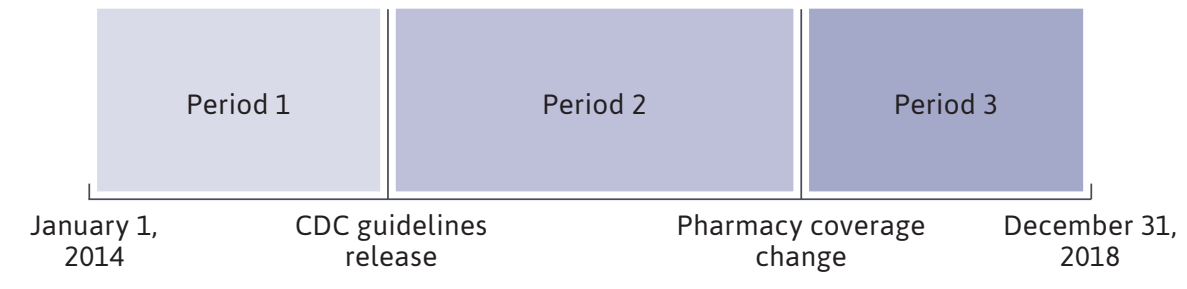

$C D C$ guidelines release $=$ March 15, 2016; extended-release payer pharmacy coverage change $=$ January 1 , 2017; opioid dose $\geq 50 \mathrm{MME}$ /day pharmacy coverage change. March 1, 2018

The study subjects were required to have a baseline period of six months of continuous enrollment with medical and pharmacy coverage prior to their first opioid prescription and to be opioid naive (have no opioid prescriptions in the baseline period). Prescriptions of all starting opioid doses, including tramadol (but excluding buprenorphine and methadone, which are opioids used in treating opioid addiction), were included. Patients with any cancer diagnosis codes and hospice care codes (Supplementary Materials, available in online article) in the baseline period were excluded. Patients were required to be 18 years or older and have a chronic pain condition ICD (International Classification of Diseases) diagnosis identified via literature review ${ }^{27-55}$ and board-certified physician inputs (Supplementary Materials, available in online article) within two weeks prior to first-time opioid prescription. This study was considered IRB exempt by the University of Minnesota Institutional Review Board because the data was existing and deidentified.

\section{OUTCOMES}

The unit of observation was the first opioid prescription per patient in the study period. We categorized first opioid prescription fills in three ways: (1) extended-release opioid;56 (2) starting daily dose of at least $50 \mathrm{MME}$ per day, calculated using the $\mathrm{CDC}$ formula (MME per day=strength per unit $\times$ (Number of units $\div$ days supply) $\times$ MME conversion factor); ${ }^{18,56}$ and (3) first-time opioid fills with benzodiazepine ${ }^{57}$ overlap were flagged when patients have a concurrent benzodiazepine fill days supply overlapping with their first-time opioid prescription fill day. We evaluated the three outcomes across different provider types and specialties.

\section{COVARIATES}

We adjusted for patient age at the time of first-time opioid prescription and number of Elixhauser comorbidities ${ }^{58}$ in the baseline as continuous variables, gender, patient insurance type (commercial or MA), census region, and residence in a metropolitan or nonmetropolitan primary care service area (PCSA) were treated as categorical variables. Each of the Elixhauser commodities were flagged as an indicator variable in the baseline, and the total number of Elixhauser comorbidities in the baseline were counted per patient and treated as a continuous variable. PCSAs are standardized systems of nongeographical units that measure access to primary care resources, utilization, supply, and associated outcomes. ${ }^{59}$ Patients were assigned to PCSAs using their zip codes according to the Dartmouth Atlas.$^{60}$ A single PCSA is made up of several census tracts. We calculated the population-weighted proportion of census tracts classified with a USDA rural-urban commuting area (RUCA) codes of three or lower. ${ }^{61}$ If the weighted proportion was greater than or equal to 0.75 , then the PCSA was considered to be metropolitan and if the weighted proportion was less than 0.75 , the PCSA was considered to be nonmetropolitan.

\section{STATISTICAL ANALYSIS}

To answer the first and second research questions, a segmented regression discontinuity linear probability model (Equation 1) was used to examine immediate change in level and monthly change in rate over time in prescription of first-time extended-release opioids and first-time opioid doses of at least 50 MME per day. The change in level and monthly change were examined before and after the CDC guidelines and also before and after the payer pharmacy coverage changes (see Equation 1 and Figure 1). To answer the third research question, we used a segmented regression discontinuity linear probability model to examine change in level and monthly change in rate overtime in first-time opioid prescription with benzodiazepine overlap before and after the CDC guidelines (see Equation 2 and Figure 2).

\section{EQUATION 1}

$$
\begin{array}{r}
y_{i}=\beta_{0}+\beta_{1} \times \text { Months }+\beta_{2} \times \mathrm{CDC}_{\text {guideline }}+\beta_{3} \times \\
\text { MonthsSinceCDC } C_{\text {guideline }}+\beta_{4} \times \text { Payer }_{\text {policy }} \\
\text { change }+\beta_{5} \times \\
\text { MonthsSincePayer } r_{\text {policychange }}+\beta_{6} \times \mathrm{X}_{i}+\beta_{i}
\end{array}
$$

\section{EQUATION 2}

$$
\begin{gathered}
y_{i}=\beta_{0}+\beta_{1} \times \text { Months }+\beta_{2} \times \mathrm{CDC}_{\text {guideline }}+\beta_{3} \times \\
\text { MonthsSinceCDC } C_{\text {guideline }}+\beta_{6} \times \mathrm{X}_{i}+\beta_{i}
\end{gathered}
$$

The equations tease out immediate change in outcome measures as well as changes in trajectory (slope) over time following each intervention (CDC guideline and payer coverage 


\section{FIGURE 2 Two Time Period Diagram}

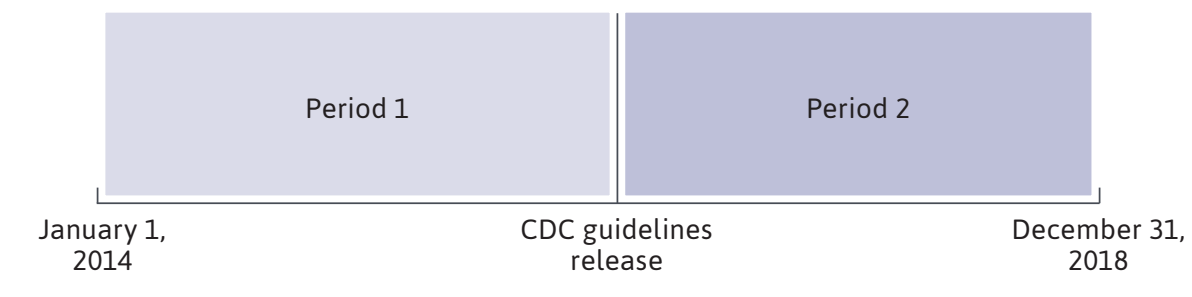

CDC guidelines release $=$ March 15, 2016

change). We chose a linear probability model over a logit model to produce readily interpretable and constant marginal effects over the entire range of outcome measures ${ }^{62,63}$ and to show change in prescription patterns after implementation of the CDC guidelines and payer coverage changes. We conducted stratified analyses among each provider type (ie, primary care, specialists, and providers with unknown specialty) as well as within each provider specialty (ie, family practice, internal medicine, OB/GYN and pediatrics, emergency medicine, internal medicine specialist, surgeons, other specialist and providers with unknown specialty) to examine how each provider group responded to the CDC guidelines and payer pharmacy coverage changes.

Changes in first-time extendedrelease and first-time opioid doses of at least 50 MME per day were analyzed as a one-time change in level (intercept) at the time of exposure to the $\mathrm{CDC}$ guidelines, change in trend over time following the CDC guidelines (Period 2 slope-Period 1 slope, see Figure 1), one-time change in level (intercept) at the time of exposure to the payer pharmacy coverage change, and change in trend over time following the payer pharmacy coverage changes (Period 3 slope-Period 2 slope, see Figure 1). Changes in first-time opioid prescription with benzodiazepine overlap were analyzed as a one-time change in level (intercept) at the time of exposure to the CDC guidelines and change in trend over time following the CDC guidelines Figure 2). All models were controlled for age, sex, number of Elixhauser comorbidities in the baseline, patient insurance type (commercial or MA), census region, and patients residing in a metropolitan vs nonmetropolitan PCSA. All analyses were performed using DbVisualizer version 10.0.15 sql server ${ }^{64}$ and Stata $14 .{ }^{65}$ Holm's sequential Bonferroni procedure adjusted $\alpha$ level of significance (target a level 0.05 /(number of tests-rank number of degree of significance +1$)^{66}$ was also applied to ensure all $P$ values remained significant for post hoc comparisons.

\section{RESULTS}

The study sample included 550,969 subjects of which $57.10 \%$ were female (Table 1). The mean age was 57.68 (SD 16.52), 59.16\% were commercially insured (others had insurance through the MA program), and $83.11 \%$ lived in metropolitan PCSAs. The mean number of Elixhauser comorbidities per patient prior to first-time opioid prescription was 1.79 (SD 1.96). Subjects were geographically dispersed, with $47.15 \%$ living in the South, $28.59 \%$ in the Midwest, $14.01 \%$ in the West, and (Period 2 slope-Period 1 slope, see
$10.25 \%$ in the Northeast and the US territories. Of all first-time opioid prescriptions, $29.12 \%$ were written by primary care providers, $42.35 \%$ by specialists, and $28.53 \%$ by providers whose specialty was unknown.

\section{UNADJUSTED RATES}

Of all first opioid prescription fills during the study period, $0.59 \%$ were with extended-release opioids, $14.13 \%$ had doses of at least 50 MME per day, and $6.39 \%$ overlapped with a benzodiazepine fill.

\section{ADJUSTED RATES}

First-time opioid fills with extendedrelease opioids. Tables 2 and 3 show the adjusted rates of first-time opioid prescriptions with extended-release opioids among different provider types and specific provider specialties. Among all providers, prior to the release of the CDC guidelines (Period 1 slope, see Figure 1), the rate of first-time opioid prescriptions with extended-release opioids decreased monthly at approximately 5.84 in every 10,000 prescriptions $(\mathrm{CI}=-10.01$ to $-1.67, \mathrm{P}=0.006)$. After the release of the CDC guidelines, there was neither an associated immediate change in level nor a change in trend over time. Subsequently, following the payer pharmacy coverage change in January 2017, no immediate change in level of first-time extended-release opioid prescription occurred, but there was an associated bigger decrease in trend by 21.48 in every 10,000 prescriptions $(\mathrm{CI}=-40.04$ to $-2.92, \mathrm{P}<0.008)$ (change in slope, Period 3 slope-Period 2 slope, Figure 1).

First-time opioid prescriptions with dose of at least $50 \mathrm{MME}$ per day. Tables 2 and 4 show the association between the CDC guidelines and payer pharmacy coverage change, with starting opioid prescriptions at doses of at least 50 MME per day among different 
provider types and among specific provider specialties. Prior to the release of the CDC guidelines, among all providers, the rate of initiating opioid prescriptions with doses of at least 50 MME per day increased monthly by 10.51 in every 10,000 prescriptions (Period 1 slope, Figure $1 ; \mathrm{CI}=8.49$ to $12.54, \mathrm{P}<0.001)$. After the release of the CDC guideline, there was an immediate decrease in level of prescriptions of firsttime opioid at doses of at least 50 MME per day by 74.00 in every 10,000 prescriptions $(\mathrm{CI}=-124.86$ to $-23.13, \mathrm{P}<0.001)$ and an associated bigger decrease in trend by 13.64 in every 10,000 prescriptions (change in slope, Period 2-Period 1, see Figure 1; $\mathrm{CI}=-17.07$ to $-10.21, \mathrm{P}<0.001)$. Following payer pharmacy coverage change in March 2018, we saw an immediate drop in level of prescription of first-time opioid dose of at least 50 MME per day by approximately 967.73 in every 10,000 prescriptions $(\mathrm{CI}=-1,020.06$ to $-915.40, \mathrm{P}<0.001)$ and a continued decrease in trend over time by 18.74 in every 10,000 prescriptions more than the period before the payer pharmacy coverage change (change in slope, Period 3 - Period 2, see Figure 1; $\mathrm{CI}=-25.98$ to $-11.51, \mathrm{P}<0.001$ ).

Prior to the CDC guidelines, first-time opioid prescriptions from primary care providers at doses 50 MME per day were already declining by 6.44 in every 10,000 prescriptions (Period 1 slope, see Figure 1; Table 2; CI=-8.96 to -3.91, $P<0.001)$. Post-CDC guidelines, we saw no further change in level or rate of decline (change in slope, Period 2 -Period 1, Figure 1). However, following payer pharmacy coverage change in March 2018, we saw an immediate decrease in the level of prescription of first-time opioid at doses of at least 50 MME per day by approximately 22.90 in every 10,000 prescriptions $(\mathrm{CI}=-293.68$ to $-164.30, \mathrm{P}<0.001)$ among primary care providers, and 1,625.79 in every 10,000 prescriptions among specialist providers $(\mathrm{CI}=-1,720.85$ to $-1,530.72, P=0.001)$. Following the payer pharmacy coverage changes, the prescription rate of first-time opioid at doses of at least $50 \mathrm{MME}$ per day declined faster by 10.91 in every 10,000 prescriptions $(\mathrm{CI}=-19.85$ to $-1.96, \mathrm{P}=0.017)$ among primary care providers, and 24.44 in every 10,000 prescriptions $(\mathrm{CI}=-37.49$ to $-11.39, \mathrm{P}<0.001)$ among specialist providers (change in slope, Period 3 -Period 2, Figure 1).

Table 4 shows the association between the CDC guidelines and payer pharmacy coverage changes with first-time opioid prescriptions at doses of at least 50 MME per day among specific provider specialties. Post-CDC guidelines release, among surgeons and providers with unknown specialty, there was an increased rate of decline in first-time opioid prescriptions at doses of at least $50 \mathrm{MME}$ per day by 29.80 and 17.66 in every 10,000 prescription $(\mathrm{CI}=-37.76$ to -21.83 and -23.61 to -11.61 respectively, $\mathrm{P}<0.001$ and $\mathrm{P}<0.001$ respectively; change in slope, Period 2-Period 1, Figure 1). Subsequently, the payer pharmacy coverage change in
March 2018 was associated with an immediate drop in level of prescriptions of first-time opioid doses of at least 50 MME per day among every specialty except internal medicine subspecialists. Among surgeons, the payer pharmacy coverage change was associated with a decrease in trend of prescriptions of first-time opioid doses of at least $50 \mathrm{MME}$ per day by 30.97 in every 10,000 prescriptions-more than the period before the payer pharmacy coverage changes (change in slope, Period 3 - Period 2, see Figure 1; CI =-48.60 to $-13.34, \mathrm{P}<0.001)$.

First-time opioid prescriptions with benzodiazepine overlap. Tables 2 and 5 show the association between the CDC guideline release and first-time opioid prescriptions with benzodiazepines overlap among different provider types and among specific provider specialties. Among all providers, prior to the release of the CDC guidelines, the rate of prescribing first-time opioids with benzodiazepine overlap was decreasing by 1.67 in every 10,000 opioid prescriptions $(\mathrm{CI}=-2.95$ to $-0.38, \mathrm{P}=0.011)$. Post-CDC guidelines, we saw an immediate decline in the level of first-time opioid prescriptions with benzodiazepine overlap by 30.32 in every 10,000 prescriptions $(\mathrm{CI}=-59.38$ to $-1.26, \mathrm{P}=0.041)$ and $\mathrm{a}$ bigger decline in trend over time by 6.27 in every 10,000 prescriptions $(\mathrm{CI}=-7.72$ to $-4.81, \mathrm{P}<0.001$; change in slope, Period 2-Period 1, Figure 2).

Following the CDC guidelines, we saw no immediate change in level of prescribing first-time opioid with benzodiazepine overlap among primary care providers or specialist providers; however, we did see an immediate decrease among providers with unknown specialty by 81.41 in every 10,000 prescriptions $(\mathrm{CI}=-137.675$ to $-25.1, \mathrm{P}=0.005)$. However, over time we observed a larger decrease in the rate of this overlap than in the period prior to the CDC guidelines (change in slope, Period 2-Period 1, Figure 2) by $6.11,5.10$, and 9.11 per every 10,000 first-time opioid prescriptions $(\mathrm{CI}=-8.21$ to $-2.82,-6.75$ to -2.38 , and -11.96 to -6.25 respectively, $\mathrm{P}<0.001, \mathrm{P}<0.001$, and $\mathrm{P}<0.001$ respectively) among primary care providers, specialist providers and providers with unknown specialty.

\section{Discussion}

We evaluated three CDC guidelines and two related payer pharmacy coverage changes for possible association with changes in opioid initiating behavior among different provider types and specialties. Some prior work has assessed the impact of the CDC guidelines on prescribing extendedrelease opioids, opioid doses of at least 90 MME per day ${ }^{19}$ and opioid prescription with benzodiazepine overlap ${ }^{20}$; however, these studies did not identify and focus on opioid 


\section{TABLE 2} Changes in Prescription of First-Time Extended-Release Opioids, First-Time Opioid Dose of at Least
50 MME Per Day, and First-Time Opioid Prescription with Benzodiazepine Overlap Associated with
CDC Guideline Release and Payer Pharmacy Coverage Changes Across Provider Types

\begin{tabular}{|c|c|c|c|c|c|}
\hline & $\begin{array}{l}\text { Pre-CDC guideline } \\
\text { slope }[\mathrm{CI}][\mathrm{P} \text { value] }\end{array}$ & $\begin{array}{c}\text { Immediate level } \\
\text { change post-CDC } \\
\text { guideline [CI] [P value] }\end{array}$ & $\begin{array}{c}\text { Post-CDC guideline } \\
\text { change in slope }[\mathrm{CI}][\mathrm{P} \\
\text { value] }\end{array}$ & $\begin{array}{c}\text { Immediate level } \\
\text { change post pharmacy } \\
\text { coverage change }[\mathrm{CI}] \\
{[\mathrm{P} \text { value] }}\end{array}$ & $\begin{array}{l}\text { Post pharmacy cover- } \\
\text { age change, change in } \\
\text { slope [CI] [P value] }\end{array}$ \\
\hline \multicolumn{6}{|c|}{ First-time extended-release opioid prescription per 100,000 prescriptions } \\
\hline $\begin{array}{l}\text { All providers } \\
(\mathrm{N}=550,969)\end{array}$ & $\begin{array}{c}-5.84 \\
(-10.01 \text { to }-1.67) \\
0.006\end{array}$ & $\begin{array}{c}22.15 \\
(-108.37 \text { to } 152.67) \\
0.739\end{array}$ & $\begin{array}{c}12.95 \\
(-9.48 \text { to } 35.38) \\
0.258\end{array}$ & $\begin{array}{c}-68.90 \\
(-212.19 \text { to } 74.38) \\
0.346\end{array}$ & $\begin{array}{c}-21.48 \\
(-40.04 \text { to }-2.92) \\
0.013\end{array}$ \\
\hline $\begin{array}{l}\text { Primary care providers } \\
(\mathrm{N}=160,447)\end{array}$ & $\begin{array}{c}-4.78 \\
(-10.52 \text { to } 0.97) \\
0.103 \\
\end{array}$ & $\begin{array}{c}-28.42 \\
(-211.53 \text { to } 154.69) \\
0.761\end{array}$ & $\begin{array}{c}20.01 \\
(-12.46 \text { to } 52.48) \\
0.227)\end{array}$ & $\begin{array}{c}-76.09 \\
(-294.54 \text { to } 142.36) \\
0.495\end{array}$ & $\begin{array}{c}-27.68 \\
(-64.75 \text { to } 9.39) \\
0.143 \\
\end{array}$ \\
\hline $\begin{array}{l}\text { Specialist providers } \\
(\mathrm{N}=233,308)\end{array}$ & $\begin{array}{c}-11.38 \\
(-18.39 \text { to }-4.38) \\
0.001\end{array}$ & $\begin{array}{c}126.72 \\
(-91.28 \text { to } 344.73) \\
0.255\end{array}$ & $\begin{array}{c}-6.55 \\
(-43.15 \text { to } 30.04) \\
0.726\end{array}$ & $\begin{array}{c}-4.40 \\
(-23.32 \text { to } 222.52) \\
0.970\end{array}$ & $\begin{array}{c}6.63 \\
(-34.60 \text { to } 47.86) \\
0.753\end{array}$ \\
\hline $\begin{array}{l}\text { Unknown providers } \\
(\mathrm{N}=157,214)\end{array}$ & $\begin{array}{c}-2.06 \\
(-10.86 \text { to } 6.75) \\
0.647\end{array}$ & $\begin{array}{c}-92.03 \\
(-349.92 \text { to } 164.86) \\
0.483\end{array}$ & $\begin{array}{c}37.16 \\
(-6.78 \text { to } 81.10) \\
0.097\end{array}$ & $\begin{array}{c}-164.23 \\
(-448.54 . \text { to } 120.07 .) \\
0.258\end{array}$ & $\begin{array}{c}-56.74 \\
(-106.65 \text { to }-6.83) \\
0.026\end{array}$ \\
\hline \multicolumn{6}{|c|}{ First-time opioid dose $\geq 50 \mathrm{MME} /$ day per 10,000 prescriptions } \\
\hline $\begin{array}{l}\text { All providers } \\
(\mathrm{N}=550,969)\end{array}$ & $\begin{array}{l}\quad 10.51 \\
(8.49 \text { to } 12.54) \\
<0.001\end{array}$ & $\begin{array}{c}-74.00 \\
(-124.86 \text { to }-23.13) \\
0.004\end{array}$ & $\begin{array}{c}-13.64 \\
(-17.07 \text { to }-10.21) \\
<0.001\end{array}$ & $\begin{array}{c}-967.73 \\
(-1,020.06 \text { to }-915.40) \\
<0.001\end{array}$ & $\begin{array}{c}-18.74 \\
(-25.98 \text { to }-11.51) \\
<0.001\end{array}$ \\
\hline $\begin{array}{l}\text { Primary care providers } \\
(\mathrm{N}=160,447)\end{array}$ & $\begin{array}{l}-6.44 \\
(-8.96 \text { to }-3.91) \\
<0.001\end{array}$ & $\begin{array}{c}-41.97 \\
(-104.30 \text { to } 20.37) \\
0.187\end{array}$ & $\begin{array}{c}3.40 \\
(-0.82 \text { to } 7.62) \\
0.114\end{array}$ & $\begin{array}{c}-22.90 \\
(-293.68 \text { to }-164.30) \\
<0.001\end{array}$ & $\begin{array}{c}-10.91 \\
(-19.85 \text { to }-1.96) \\
0.017\end{array}$ \\
\hline $\begin{array}{l}\text { Specialist providers } \\
(\mathrm{N}=233,308)\end{array}$ & $\begin{array}{l}10.06 \\
(6.58 \text { to } 13.54) \\
\quad<0.001\end{array}$ & $\begin{array}{c}-30.56 \\
(-114.96 \text { to } 53.85) \\
0.478\end{array}$ & $\begin{array}{c}-17.33 \\
(-23.17 \text { to }-11.48) \\
<0.001\end{array}$ & $\begin{array}{c}-1,625.79 \\
(-1,720.85 \text { to }-1,530.72) \\
<0.001\end{array}$ & $\begin{array}{c}-24.44 \\
(-37.49 \text { to }-11.39) \\
<0.001\end{array}$ \\
\hline $\begin{array}{l}\text { Unknown providers } \\
(\mathrm{N}=157,214)\end{array}$ & $\begin{array}{l}10.98 \\
(7.02 \text { to } 14.94) \\
<0.001\end{array}$ & $\begin{array}{c}-98.44 \\
(-188.62 \text { to }-8.26) \\
0.032\end{array}$ & $\begin{array}{c}-17.66 \\
(-23.61 \text { to }-11.61) \\
<0.001\end{array}$ & $\begin{array}{c}-723.20 \\
(-808.86 \text { to }-637.75) \\
<0.001\end{array}$ & $\begin{array}{c}-6.81 \\
(-18.75 \text { to } 5.12) \\
0.263\end{array}$ \\
\hline \multicolumn{6}{|c|}{ First-time opioid with benzodiazepine overlap per 10,000 prescriptions } \\
\hline $\begin{array}{l}\text { All providers } \\
(\mathrm{N}=550,969)\end{array}$ & $\begin{array}{c}-1.67 \\
(-2.95 \text { to }-0.38) \\
0.011\end{array}$ & $\begin{array}{c}-30.32 \\
(-59.38 \text { to }-1.26) \\
0.041\end{array}$ & $\begin{array}{l}-6.27 \\
(-7.72 \text { to }-4.81) \\
<0.001\end{array}$ & & \\
\hline $\begin{array}{l}\text { Primary care providers } \\
(\mathrm{N}=160,447)\end{array}$ & $\begin{array}{c}-1.94 \\
(-4.20 \text { to } 0.33) \\
0.094\end{array}$ & $\begin{array}{c}12.37 \\
(-41.79 \text { to } 66.53) \\
0.654\end{array}$ & $\begin{array}{c}-5.51 \\
(-8.21 \text { to }-2.82) \\
<0.001\end{array}$ & & \\
\hline $\begin{array}{l}\text { Specialist providers } \\
(\mathrm{N}=233,308)\end{array}$ & $\begin{array}{c}2.89 \\
(4.82 \text { to }-0.96) \\
0.003 \\
\end{array}$ & $\begin{array}{c}-30.49 \\
(-72.87 \text { to } 11.88) \\
0.158\end{array}$ & $\begin{array}{l}-4.56 \\
(-6.75 \text { to }-2.38) \\
\quad<0.001\end{array}$ & & \\
\hline $\begin{array}{l}\text { Unknown providers } \\
(\mathrm{N}=157,214)\end{array}$ & $\begin{array}{c}0.36 \\
(-2.31 \text { to } 3.03) \\
0.792\end{array}$ & $\begin{array}{c}-81.41 \\
(-137.675 \text { to }-25.1) \\
0.05\end{array}$ & $\begin{array}{c}-9.11 \\
(-11.96 \text { to }-6.25) \\
<0.001\end{array}$ & & \\
\hline
\end{tabular}

Note: Models adjusted for patient age, sex, number of Elixhauser comorbidities, insurance type, census region and residence in a metropolitan primary care service area. All statically significant $P$ values remain significant after Holm's sequential Bonferroni adjustment.

$\mathrm{SE}=$ robust standard error; $\mathrm{MME}=$ morphine milligram equivalent; $\mathrm{OB}=$ obstetrics; $G Y N=$ gynecology.

initiation patterns in patients with chronic pain condition ICD codes across different provider specialties. Our study adds to the literature by describing changes in opioid initiation and ensuring that all subjects had an identified chronic pain condition within two weeks prior to their first-time opioid prescriptions. Ensuring subjects have a chronic pain condition prior to opioid initiationis important because the CDC guidelines are recommended specifically for chronic 


\section{TABLE 3} Changes in First-Time Opioid Prescription with Extended-Release Associated with CDC Guideline
Release and Payer Pharmacy Coverage Changes Across Different Provider Specialties

\begin{tabular}{|c|c|c|c|c|c|}
\hline & $\begin{array}{l}\text { Pre-CDC } \\
\text { guideline slope } \\
\text { (CI) } P \text { value }\end{array}$ & $\begin{array}{l}\text { Immediate level } \\
\text { change post-CDC } \\
\text { guideline } \\
\text { (CI) } P \text { value }\end{array}$ & $\begin{array}{l}\text { Post-CDC } \\
\text { guideline change } \\
\text { in slope } \\
\text { (CI) } P \text { value }\end{array}$ & $\begin{array}{l}\text { Immediate level } \\
\text { change post pharmacy } \\
\text { coverage change } \\
\text { (CI) } P \text { value }\end{array}$ & $\begin{array}{l}\text { Post pharmacy } \\
\text { coverage change, } \\
\text { change in slope } \\
\text { (CI) } P \text { value }\end{array}$ \\
\hline \multicolumn{6}{|c|}{ Primary care providers first-time extended-release opioid prescriptions per 100,000 prescriptions } \\
\hline $\begin{array}{l}\text { Family medicine } \\
(\mathrm{N}=99,091)\end{array}$ & $\begin{array}{c}-37.60 \\
(-10.76 \text { to } 3.25) \\
0.293\end{array}$ & $\begin{array}{c}-11.72 \\
(-235.39 \text { to } 211.95) \\
0.918\end{array}$ & $\begin{array}{c}19.96 \\
(-19.79 \text { to } 59.71) \\
0.325\end{array}$ & $\begin{array}{c}-188.47 \\
(-465.28 \text { to } 88.33) \\
0.182\end{array}$ & $\begin{array}{c}-24.80 \\
(-69.93 \text { to } 20.34) \\
0.282\end{array}$ \\
\hline $\begin{array}{l}\text { Internal medicine } \\
(\mathrm{N}=55,507)\end{array}$ & $\begin{array}{c}-7.36 \\
(-18.02 \text { to } 3.30) \\
0.176)\end{array}$ & $\begin{array}{c}-67.16 \\
(-394.87 \text { to } 260.54) \\
0.688\end{array}$ & $\begin{array}{c}28.77 \\
(-30.21 \text { to } 87.75) \\
0.339\end{array}$ & $\begin{array}{c}56.35 \\
(-332.38 \text { to } 445.09) \\
0.776\end{array}$ & $\begin{array}{c}-39.56 \\
(-107.27 \text { to } 28.15) \\
0.252\end{array}$ \\
\hline $\begin{array}{l}\mathrm{OB} / \mathrm{GYN} \text { and pediatrics } \\
(\mathrm{N}=5,849)\end{array}$ & $\begin{array}{c}51.80 \\
(-16.32 \text { to } 26.69) \\
0.636\end{array}$ & $\begin{array}{c}7.76 \\
(-1,059.17 \text { to } 1,074.69) \\
0.989\end{array}$ & $\begin{array}{c}-60.04 \\
(-224.61 \text { to } 104.52) \\
0.474\end{array}$ & $\begin{array}{c}499.50 \\
(-109.81 \text { to } 1,108.81) \\
0.108\end{array}$ & $\begin{array}{c}39.42 \\
(-155.78 \text { to } 234.63) \\
0.692\end{array}$ \\
\hline \multicolumn{6}{|c|}{ Specialist providers first-time extended- release opioid prescriptions per 100,000 prescriptions } \\
\hline $\begin{array}{l}\text { Surgeons } \\
(N=148,205)\end{array}$ & $\begin{array}{c}-13.98 \\
(-24.10 \text { to }-3.86) \\
0.007\end{array}$ & $\begin{array}{c}90.84 \\
(-208.39 \text { to } 390.07) \\
0.552\end{array}$ & $\begin{array}{c}-1.64 \\
(50.57 \text { to } 47.28) \\
0.948\end{array}$ & $\begin{array}{c}-30.62 \\
(-334.61 \text { to } 273.37) \\
0.843\end{array}$ & $\begin{array}{c}-2.86 \\
(-57.93 \text { to } 52.22) \\
0.919\end{array}$ \\
\hline $\begin{array}{l}\text { Internal medicine } \\
\text { subspecialist } \\
(\mathrm{N}=14,937)\end{array}$ & $\begin{array}{c}4.45 \\
(-22.00 \text { to } 30.90) \\
0.741\end{array}$ & $\begin{array}{c}307.93 \\
(-739.22 \text { to } 1,355.09) \\
0.564\end{array}$ & $\begin{array}{c}-91.05 \\
(-265.81 \text { to } 83.71) \\
0.307\end{array}$ & $\begin{array}{c}123.33 \\
(-899.86 \text { to } 1,146.52) \\
0.813\end{array}$ & $\begin{array}{c}114.09 \\
(-81.35 \text { to } 309.53) \\
0.253\end{array}$ \\
\hline $\begin{array}{l}\text { Emergency medicine } \\
(\mathrm{N}=47,729)\end{array}$ & $\begin{array}{c}-2.23 \\
(-5.94 \text { to } 1.48) \\
0.238\end{array}$ & $\begin{array}{c}-18.07 \\
(-105.11 \text { to } 68.96) \\
0.684\end{array}$ & $\begin{array}{c}6.81 \\
(-9.25 \text { to } 22.87) \\
0.406 \\
\end{array}$ & $\begin{array}{c}14.59 \\
(-130.76 \text { to } 159.95) \\
0.844\end{array}$ & $\begin{array}{c}-84.20 \\
(-27.71 \text { to } 10.86) \\
0.392\end{array}$ \\
\hline $\begin{array}{l}\text { Other specialists } \\
(N=22,437)\end{array}$ & $\begin{array}{c}-31.57 \\
(-57.89 \text { to }-5.25) \\
0.019\end{array}$ & $\begin{array}{c}453.28 \\
(-408.16 \text { to } 1,314.71) \\
0.302\end{array}$ & $\begin{array}{c}-29.10 \\
(-177.81 \text { to } 119.61) \\
0.701\end{array}$ & $\begin{array}{c}78.03 \\
(-784.05 \text { to } 940.11) \\
0.859\end{array}$ & $\begin{array}{c}62.88 \\
(-104.26 \text { to } 230.02) \\
0.461\end{array}$ \\
\hline
\end{tabular}

Note: Models adjusted for patient age, sex, number of Elixhauser comorbidities, insurance type, census region and residence in a metropolitan primary care service area. All statically significant $P$ values remain significant after Holm's sequential Bonferroni adjustment.

$S E=$ robust standard error; $M M E=$ morphine milligram equivalent; $O B=$ obstetrics; $G Y N=$ gynecology.

pain. Furthermore, we excluded subjects to whom the guidelines did not apply (those who had cancer diagnoses or had received hospice care in the baseline period). Also, our study adds to work by Jeffery et $\mathrm{al}^{20}$ (which evaluated opioid prescription overlap with benzodiazepine over the full course of opioid treatment) by specifically evaluating the impact of the CDC guidelines on initiating opioid prescription with benzodiazepine overlap across multiple provider specialties. Also, because payer pharmacy coverage changes are known tools for shaping provider prescribing behavior, ${ }^{67}$ our work sought to better illuminate differences in the association of some payer pharmacy coverage changes with changes in opioid initiating behavior across provider specialties.

Among all providers, we found no association between the CDC guidelines release and not starting first-time opioid prescription with extended-release opioids-a finding consistent with the literature. However, a payer pharmacy coverage change in January 2017, requiring prior authorization and provider attestation before initiating opioids with extended-release rather than immediate-release opioids, was associated with a decline in first-time extendedrelease opioids prescription. While the CDC guideline was not associated with change in prescribing behavior, the payer pharmacy coverage change was, which highlights the importance of a multi-interventional approach for shaping provider opioid prescribing behavior.

Similarly, we found that across all providers, the CDC guideline was associated with an immediate decline in level and continued decline in rate of prescriptions of first-time opioids at doses of at least 50 MME per day. However, we also found that the payer pharmacy coverage change in March 2018 was associated with a larger immediate decline in level and continued decline in the monthly rate of 


\section{TABLE 4 Changes in First-Time Opioid Prescription with Doses of at Least 50 MME Per Day Associated with CDC Guideline Release and Payer Pharmacy Coverage Changes Across Different Provider Specialties}

\begin{tabular}{|c|c|c|c|c|c|}
\hline & $\begin{array}{l}\text { Pre-CDC guideline } \\
\text { slope } \\
\text { (CI) } P \text { value }\end{array}$ & $\begin{array}{l}\text { Immediate level } \\
\text { change post-CDC } \\
\text { guideline } \\
\text { (CI) } P \text { value }\end{array}$ & $\begin{array}{l}\text { Post-CDC } \\
\text { guideline change } \\
\text { in slope } \\
\text { (CI) } P \text { value }\end{array}$ & $\begin{array}{l}\text { Immediate level } \\
\text { change post pharmacy } \\
\text { coverage change } \\
\text { (CI) } P \text { value }\end{array}$ & $\begin{array}{l}\text { Post pharmacy } \\
\text { coverage change, } \\
\text { change in slope } \\
\text { (CI) } P \text { value }\end{array}$ \\
\hline \multicolumn{6}{|c|}{ Primary care providers first-time opioid dose prescriptions $\geq 50 \mathrm{MME}$ day per 10,000 prescriptions } \\
\hline $\begin{array}{l}\text { Family medicine } \\
(\mathrm{N}=99,091)\end{array}$ & $\begin{array}{c}-8.23 \\
(-11.51 \text { to }-4.95) \\
<0.001\end{array}$ & $\begin{array}{c}-67.58 \\
(-148 . \text { to } 12.84) \\
0.100\end{array}$ & $\begin{array}{c}3.91 \\
(-1.55 \text { to } 9.36) \\
0.160\end{array}$ & $\begin{array}{c}-188.23 \\
(-274.89 \text { to }-101.58) \\
<0.001\end{array}$ & $\begin{array}{c}-11.80 \\
(-24.00 \text { to } 0.39) \\
0.058\end{array}$ \\
\hline $\begin{array}{l}\text { Internal medicine } \\
(N=55,507)\end{array}$ & $\begin{array}{c}-6.74 \\
(-10.38 \text { to }-3.11) \\
<0.001\end{array}$ & $\begin{array}{c}25.16 \\
(-64.35 \text { to } 114.66) \\
0.582\end{array}$ & $\begin{array}{c}3.94 \\
(-2.12 \text { to } 10.00) \\
0.202\end{array}$ & $\begin{array}{c}-141.80 \\
(-232.34 \text { to }-51.26) \\
0.002\end{array}$ & $\begin{array}{c}-1.74 \\
(-14.64 \text { to } 11.16) \\
0.791\end{array}$ \\
\hline $\begin{array}{l}\mathrm{OB} / \mathrm{GYN} \text { and pediatrics } \\
(\mathrm{N}=5,849)\end{array}$ & $\begin{array}{c}11.51 \\
(-10.22 \text { to } 33.24) \\
0.299\end{array}$ & $\begin{array}{c}-262.53 \\
(-807.02 \text { to } 281.97) \\
0.345\end{array}$ & $\begin{array}{c}-26.29 \\
(-62.39 \text { to } 9.81) \\
0.153\end{array}$ & $\begin{array}{c}-1702.00 \\
(-2,183.54 \text { to }-1,220.45) \\
<0.001\end{array}$ & $\begin{array}{c}-12.45 \\
(-66.10 \text { to } 41.18) \\
0.649\end{array}$ \\
\hline \multicolumn{6}{|c|}{ Specialist providers first-time opioid dose prescriptions $\geq 50$ MME day per 10,000 prescriptions } \\
\hline $\begin{array}{l}\text { Surgeons } \\
(\mathrm{N}=148,205)\end{array}$ & $\begin{array}{c}14.58 \\
(9.87 \text { to } 19.29) \\
<0.001\end{array}$ & $\begin{array}{c}-71.71 \\
(-188.59 \text { to } 45.18) \\
0.229\end{array}$ & $\begin{array}{c}-29.80 \\
(-37.76 \text { to }-21.83) \\
<0.001\end{array}$ & $\begin{array}{c}-1,954.45 \\
(-2,081.74 \text { to }-1,827.16) \\
<0.001\end{array}$ & $\begin{array}{c}-30.97 \\
(-48.60 \text { to }-13.34) \\
<0.001\end{array}$ \\
\hline $\begin{array}{l}\text { Internal medicine subspe- } \\
\text { cialist }(N=14,937)\end{array}$ & $\begin{array}{c}-3.41 \\
(-11.58 \text { to } 4.76) \\
0.413\end{array}$ & $\begin{array}{c}-94.40 \\
(-302.81 \text { to } 114.01) \\
0.375\end{array}$ & $\begin{array}{c}4.08 \\
(-10.05 \text { to } 18.21) \\
0.571\end{array}$ & $\begin{array}{c}-412.59 \\
(-625.63 \text { to }-199.54) \\
<0.001\end{array}$ & $\begin{array}{c}20.94 \\
(-12.26 \text { to } 54.14) \\
0.216\end{array}$ \\
\hline $\begin{array}{l}\text { Emergency medicine } \\
(\mathrm{N}=47,729)\end{array}$ & $\begin{array}{c}-18.44 \\
(-24.60 \text { to } 12.27) \\
<0.001\end{array}$ & $\begin{array}{c}-27.69 \\
(-177.83 \text { to } 122.46) \\
0.718)\end{array}$ & $\begin{array}{c}3.13 \\
(-7.31 \text { to } 13.56) \\
0.557\end{array}$ & $\begin{array}{c}-720.64 \\
(-873.40 \text { to }-567.87) \\
<0.001)\end{array}$ & $\begin{array}{c}2.44 \\
(-16.78 \text { to } 21.67) \\
0.803\end{array}$ \\
\hline $\begin{array}{l}\text { Other specialists } \\
(\mathrm{N}=22,437)\end{array}$ & $\begin{array}{c}14.86 \\
(5.16 \text { to } 24.6) \\
0.003\end{array}$ & $\begin{array}{c}-298.20 \\
(-544.09 \text { to }-52.30) \\
0.017\end{array}$ & $\begin{array}{c}0.96 \\
(-15.91 \text { to } 17.84) \\
0.911\end{array}$ & $\begin{array}{c}-1468.58 \\
(-1,729.28 \text { to }-1,207.88) \\
<0.001\end{array}$ & $\begin{array}{c}-22.96 \\
(-59.34 \text { to } 13.42) \\
0.216\end{array}$ \\
\hline
\end{tabular}

Note: Models adjusted for patient age, sex, number of Elixhauser comorbidities, insurance type, census region and residence in a metropolitan primary care service area. All statically significant $P$ values remain significant after Holm's sequential Bonferroni adjustment.

$S E=$ robust standard error; $M M E=$ morphine milligram equivalent; $O B=$ obstetrics; $G Y N=$ gynecology .

prescribing first-time opioid at doses of at least $50 \mathrm{MME}$ per day. These findings suggest that even when CDC guidelines are associated with changes in prescribing behavior, an additional intervention-such as the payer pharmacy coverage change-might help reinforce the guidelines.

When examining provider specialties separately, we found no association between $\mathrm{CDC}$ guidelines and prescribing first-time opioid at doses of at least 50 MME per day among primary care providers. These providers, prior to the CDC guidelines, had their rate of prescription of firsttime opioid at doses of at least 50 MME per day trending downward, but their prescribing did not further decline after the CDC guidelines. On the other hand, surgeons and other specialist providers who were, pre-guidelines, trending upward in prescribing first-time opioid at doses of at least 50 MME per day, showed a decline following the guidelines. These results reveal important differences among specialty types in response to the CDC guidelines and a notable uptake of the guidelines by nonprimary care providers.

Regarding first-time opioid prescriptions overlapping with benzodiazepines, we saw an immediate decline in level and a bigger decline in rate following the CDC guidelines among all providers (Table 2). This finding is consistent with prior literature..$^{19}$ However, when we evaluated provider specialties separately, only emergency medicine and providers with unknown specialty showed an immediate drop in level following the CDC guidelines (Table 5). The immediate decline in first-time opioid prescriptions with benzodiazepine overlap among emergency physicians following the CDC guideline may have been buttressed by the American College of Emergency Physicians clinical 


\section{TABLE 5 Changes in First-Time Opioid Initiation with Benzodiazepine Overlap Associated with CDC Guideline Release Across Different Provider Specialties}

\begin{tabular}{|c|c|c|c|}
\hline & $\begin{array}{l}\text { Pre-CDC } \\
\text { guideline slope } \\
\text { (CI) P value }\end{array}$ & $\begin{array}{l}\text { Immediate level } \\
\text { change post-CDC } \\
\text { guideline } \\
\text { (CI) } P \text { value }\end{array}$ & $\begin{array}{l}\text { Post-CDC guideline } \\
\text { change in slope } \\
\text { (CI) } P \text { value }\end{array}$ \\
\hline \multicolumn{4}{|c|}{$\begin{array}{l}\text { Primary care providers first-time opioid prescriptions with benzodiazepine overlap per } 10,000 \\
\text { prescriptions }\end{array}$} \\
\hline $\begin{array}{l}\text { Family medicine } \\
(\mathrm{N}=99,091)\end{array}$ & $\begin{array}{c}-0.64 \\
(-3.46 \text { to } 2.18) \\
0.656\end{array}$ & $\begin{array}{c}-8.58 \\
(-76.26 \text { to } 59.11) \\
0.804\end{array}$ & $\begin{array}{c}-6.11 \\
(-9.48 \text { to }-2.73) \\
<0.001\end{array}$ \\
\hline $\begin{array}{l}\text { Internal medicine } \\
(\mathrm{N}=55,507)\end{array}$ & $\begin{array}{c}-3.28 \\
(-7.29 \text { to } 0.72) \\
0.108\end{array}$ & $\begin{array}{c}32.59 \\
(-62.80 \text { to } 127.98) \\
0.503\end{array}$ & $\begin{array}{c}-5.10 \\
(-9.86 \text { to }-0.35) \\
0.035\end{array}$ \\
\hline $\begin{array}{l}\mathrm{OB} / \mathrm{GYN} \text { and pediatrics } \\
(\mathrm{N}=5,849)\end{array}$ & $\begin{array}{l}-9.93 \\
(-22.26 \text { to } 2.40) \\
0.114\end{array}$ & $\begin{array}{l}149.43 \\
(-121.04 \text { to } 419.90) \\
0.279\end{array}$ & $\begin{array}{l}3.43 \\
(-10.29 \text { to } 17.15) \\
0.624\end{array}$ \\
\hline \multicolumn{4}{|c|}{$\begin{array}{l}\text { Specialist providers first-time opioid prescription with benzodiazepine overlap per } 10,000 \\
\text { prescriptions }\end{array}$} \\
\hline $\begin{array}{l}\text { Surgeons } \\
(\mathrm{N}=148,205)\end{array}$ & $\begin{array}{c}-3.14 \\
(-5.38 \text { to }-0.91) \\
0.006\end{array}$ & $\begin{array}{c}-6.07 \\
(-55.22 \text { to } 43.08) \\
0.809\end{array}$ & $\begin{array}{c}-2.89 \\
(-5.40 \text { to }-0.38) \\
0.024\end{array}$ \\
\hline $\begin{array}{l}\text { Internal medicine } \\
\text { specialist }(\mathrm{N}=14,937)\end{array}$ & $\begin{array}{c}-2.13 \\
(-9.98 \text { to } 5.72) \\
0.594\end{array}$ & $\begin{array}{c}81.99 \\
(-113.25 \text { to } 277.23) \\
0.410\end{array}$ & $\begin{array}{c}-8.22 \\
(17.81 \text { to } 1.38) \\
0.093\end{array}$ \\
\hline $\begin{array}{l}\text { Emergency medicine } \\
(\mathrm{N}=47,729)\end{array}$ & $\begin{array}{l}1.43 \\
(-3.52 \text { to } 6.37) \\
0.572\end{array}$ & $\begin{array}{c}-119.09 \\
(-234.00 \text { to }-4.18) \\
0.042\end{array}$ & $\begin{array}{c}-11.43 \\
(-17.26 \text { to }-5.61) \\
<0.001\end{array}$ \\
\hline $\begin{array}{l}\text { Other specialists } \\
(\mathrm{N}=22,437)\end{array}$ & $\begin{array}{c}-7.22 \\
(-13.41 \text { to }-1.03) \\
0.022\end{array}$ & $\begin{array}{c}29.93 \\
(-108.85 \text { to } 168.71) \\
0.673\end{array}$ & $\begin{array}{c}1.71 \\
(-5.43 \text { to } 8.85) \\
0.639\end{array}$ \\
\hline
\end{tabular}

Note: Models adjusted for patient age, sex, number of Elixhauser comorbidities, insurance type, census region and residence in a metropolitan primary care service area. All statically significant $P$ values remain significant after Holm's sequential Bonferroni adjustment.

$\mathrm{SE}=$ robust standard error; $\mathrm{MME}=$ morphine milligram equivalent, $\mathrm{OB}=$ obstetrics, $\mathrm{GYN}=$ gynecology.

policy on opioid prescribing that also discourages coprescriptions. ${ }^{68,69}$ However, following the CDC guideline release, there was a decrease in rate of prescribing first-time opioids overlapping with benzodiazepines among all specialty categories except three: internal medicine subspecialists, OB/GYN and pediatricians, and other specialists (Table 5). This finding underscores the need for a better understanding of opioid prescribing behaviors within specialties in order to better target newer policies and future guideline recommendations.

\section{LIMITATIONS}

Our results show an association rather than a causal effect of guidelines and payer pharmacy coverage changes on provider prescribing behavior. In the claims data, we only observe opioid fills and not all written prescriptions by providers, and the data may be missing prescriptions paid out-of-pocket. The data are also missing some important populations, including Medicaid, VA, and uninsured people. Finally, our analysis did not seek to identify or account for any state or hospital-level policies on opioid prescribing during the study period.

\section{Conclusions}

The response to the $\mathrm{CDC}$ guidelines and payer pharmacy coverage changes varied across provider specialties. Among all providers, CDC guidelines were associated with reduced firsttime opioid prescription at doses of at least 50 MME per day and reduced first-time prescriptions with overlapping benzodiazepines, but not with reduced prescription of first-time extended-release opioids. Payer pharmacy coverage changes, however, were associated with not only reduced first-time opioid prescriptions at doses of at least $50 \mathrm{MME}$ per day but also with reduced first-time prescription of extended-release opioids, thereby reinforcing the CDC guidelines. These findings underscore the importance of a multi-intervention approach when attempting to shape provider prescribing behavior.

\section{DISCLOSURE}

This research was funded by Agency for Healthcare Research and Quality (R01 HS025164; PI: Karaca-Mandic). KaracaMandic reports grants from the American Cancer Society and Sempre Health, along with fees from Tactile Medical and Precision Health Economics, unrelated to this study. The other authors have nothing to disclose.

\section{REFERENCES}

1. Centers for Disease Control and Prevention. About underlying cause of death, 1999-2017 request. cdc.org. Accessed October 29, 2020. https:// wonder.cdc.gov/controller/saved/D76/ D15F907 
2. Scholl L, Seth P, Kariisa M, Wilson N, Baldwin G. Drug and opioid-involved overdose deaths-United States, 20132017. MMWR Morb Mortal Wkly Rep. 2019;67(5152):1419-27. doi:10.15585/mmwr. mm6751521e1

3. US Department of Health and Human Services. What is the Opioid Epidemic? hhs.gov. Published December 4, 2017. Accessed October 29, 2020. https://www. hhs.gov/opioids/about-the-epidemic/ index.html

4. Seth P, Scholl L, Rudd RA, Bacon S. Overdose deaths involving opioids, cocaine, and psychostimulants-United States, 2015-2016. MMWR Morb Mortal Wkly Rep. 2018;67(12):349-58. doi:10.15585/ mmwr.mm6712a1

5. Clark JD. Chronic pain prevalence and analgesic prescribing in a general medical population. J Pain Symptom Manage. 2002;23(2):131-37. doi:10.1016/ s0885-3924(01)00396-7

6. National Academies of Sciences E, Division $\mathrm{H}$ and M, Policy B on HS, et al. New Report Presents National Strategy to Reduce Opioid Epidemic. National Academies Press (US); 2017. Accessed November 5, 2020. https://www. nationalacademies.org/news/2017/07/ new-report-presents-national-strategyto-reduce-opioid-epidemic

7. Phillips, JK, Ford, MA., Bonnie, RJ, \& National Academies of Sciences, Engineering, and Medicine. Trends in Opioid Use, Harms, and Treatment in Pain Management and the Opioid Epidemic: Balancing Societal and Individual Benefits and Risks of Prescription Opioid Use. National Academies Press (US); 2017. Accessed November 5, 2020. https://www.ncbi.nlm.nih.gov/books/ NBK458661/

8. Gifford A, Quach C. Prescription of opioid medications in VA outpatient care. Health Services Research and Development of Veterans Affairs. Accessed October 29, 2020. https://www. hsrd.research.va.gov/meetings/2001/ HSRD2001AMab126.htm
9. US Department of Health and Human Services. Why guidelines for primary care providers? Centers for Disease Control and Prevention. Accessed October 29, 2020. https://www.cdc.gov/drugoverdose/pdf/guideline_infographic-a.pdf

10. Porucznik CA, Johnson EM, Rolfs RT, Sauer BC. Specialty of prescribers associated with prescription opioid fatalities in Utah, 2002-2010. Pain Med. 2014;15(1): 73-78. doi:10.1111/pme.12247

11. Dowell D, Haegerich TM, Chou R. CDC guideline for prescribing opioids for chronic pain- United states, 2016. MMWR Recomm Rep. 2016;65(1):1-49. doi:10.15585/ mmwr.rr6501e1

12. Bishop PB, Wing PC. Knowledge transfer in family physicians managing patients with acute low back pain: a prospective randomized control trial. Spine J. 2006;6(3):282-88. doi:10.1016/j. spinee.2005.10.008

13. Dooks P. Diffusion of pain management research into nursing practice. Cancer Nurs. 2001;24(2):99-103. doi:10.1097/00002820-200104000-00004

14. Formoso G, Rizzini P, Bassi M, et al. Knowledge transfer: what drug information would specialist doctors need to support their clinical practice? Results of a survey and of three focus groups in Italy. BMC Med Inform Decis Mak. 2016;16(1):115. doi:10.1186/s12911-016-0355-7

15. Sanson-Fisher RW. Diffusion of innovation theory for clinical change. Med J Aust. 2004;180(S6):S55-56. doi:10.5694/j.1326-5377.2004.tb05947.x

16. US Food and Drug Administration. Questions and answers: FDA approves a risk evaluation and mitigation strategy (REMS) for extended-release and long-acting (ER/LA) opioid analgesics. fda.gov. Published July 9, 2012. Updated March 1, 2013. Accessed November 5, 2020. https://www.fda. gov/drugs/information-drug-class/ questions-and-answers-fda-approvesrisk-evaluation-and-mitigation-strategyrems-extended-release-and
17. Dowell D. CDC guideline for prescribing opioids for chronic pain. Powerpoint presented at: National Center for Injury Prevention and Control Board of Scientific Counselors Meeting; January 28, 2016. https://stacks.cdc.gov/view/cdc/38277/ cdc 38277 DS1.pdf

18. US Department of Health and Human Services. Calculating total daily dose of opioids for safer dosage. Centers for Disease Control and Prevention. Accessed November 5, 2020. https://www.cdc.gov/ drugoverdose/pdf/calculating_total_ daily dose-a.pdf. :2

19. Bohnert ASB, Guy GP, Losby JL. Opioid prescribing in the United States before and after the centers for disease control and prevention's 2016 opioid guideline. Ann Intern Med. 2018;169(6):367-75. doi:10.7326/M18-1243

20. Jeffery MM, Hooten WM, Jena AB, Ross JS, Shah ND, Karaca-Mandic P. Rates of physician coprescribing of opioids and benzodiazepines after the release of the centers for disease control and prevention guidelines in 2016. JAMA Netw Open. 2019;2(8): e198325. doi:10.1001/ jamanetworkopen.2019.8325

21. United Health Care. Working together to help end the opioid epidemic. uhc.com. Accessed November 5, 2020. https:// newsroom.uhc.com/content/dam/ newsroom/opioids/Working_Together_ to_End_the_Opioid_Epidemic_jg0zk8. pdf

22. United Health Care. Prevent, treat, support: united health care's comprehensive strategy. uhc.com. Accessed October 29, 2020. https://newsroom.uhc.com/ opioids/uhc-opioids-overview.html

23. United Health Care. New strategies for fighting opioid misuse. uhc.com. Accessed October 29, 2020. https://www. uhc.com/employer/news/consultant/ new-strategies-for-fighting-opioid-misuse

24. Scherrer JF, Tucker J, Salas J, Zhang Z, Grucza R. Comparison of opioids prescribed for patients at risk for opioid misuse before and after publication of the centers for disease control and prevention's opioid prescribing guidelines. JAMA Netw Open. 2020;3(12): e2027481. doi:10.1001/jamanetworkopen.2020.27481 
25. Optum. Retrospective Database Analysis. optum.com. Accessed October 29, 2020. https://www.optum.com/ content/dam/optum/resources/productSheets/Retrospective-Database-Analysis. pdf

26. OptumLabs. OptumLabs and OptumLabs data warehouse (OLDW) descriptions and citation. Eden Prairie, MN: n.p., July 2020. PDF. Reproduced with permission from OptumLabs.

27. Borenstein DG. Chronic low back pain. Rheum Dis Clin North Am. 1996;22(3):43956. doi:10.1016/s0889-857x(05)70281-7

28. Farrar JT, Young JP, LaMoreaux L, Werth JL, Poole RM. Clinical importance of changes in chronic pain intensity measured on an 11-point numerical pain rating scale. Pain. 2001;94(2):149-58. doi:10.1016/ s0304-3959(01)00349-9

29. Treede R-D, Rief W, Barke A, et al. A classification of chronic pain for ICD-11. Pain. 2015;156(6):1003-07. doi:10.1097/j. pain.0000000000000160

30. Scholz J, Finnerup NB, Attal N, et al. The IASP classification of chronic pain for ICD-11: chronic neuropathic pain. Pain. 2019;160(1):53-59. doi:10.1097/j. pain.0000000000001365

31. Tompkins DA, Hobelmann JG, Compton P. Providing chronic pain management in the "fifth vital sign" era: historical and treatment perspectives on a modern-day medical dilemma. Drug Alcohol Depend. 2017;173(Suppl 1):S11-S21. doi:10.1016/j.drugalcdep.2016.12.002

32. Stein SL. Chronic pelvic pain. Gastroenterol Clin North Am. 2013;42(4): 785-800. doi:10.1016/j.gtc.2013.08.005

33. van Hecke O, Torrance N, Smith BH. Chronic pain epidemiology and its clinical relevance. Br J Anaesth. 2013;111(1):13-18. doi:10.1093/bja/aet123

34. Fillingim RB, Bruehl S, Dworkin RH, et al. The ACTTION-American pain society pain taxonomy (AAPT): an evidence-based and multidimensional approach to classifying chronic pain conditions. J Pain. 2014;15(3):241-49. doi:10.1016/j.jpain.2014.01.004
35. Schwartz ES, Gebhart GF. Visceral pain. Curr Top Behav Neurosci. 2014;20:171-97. doi:10.1007/7854_2014_315

36. Addison RG. Chronic pain syndrome. Am J Med. 1984;77(3A):54-58. doi:10.1016/ s0002-9343(84)80102-3

37. Borsook D. Neurological diseases and pain. Brain. 2012;135(2):320-44. doi:10.1093/brain/awr271

38. Breivik H, Collett B, Ventafridda V, Cohen R, Gallacher D. Survey of chronic pain in Europe: prevalence, impact on daily life, and treatment. Eur J Pain. 2006;10(4):287-333. doi:10.1016/j. ejpain.2005.06.009

39. Bryce TN, Biering-Sørensen F, Finnerup NB, et al. International spinal cord injury pain classification: part I. Background and description. March 6-7 2009. Spinal Cord. 2012;50(6):413-17. doi:10.1038/sc.2011.156

40. Bryce TN, Biering-Sørensen F, Finnerup NB, et al. International spinal cord injury pain (ISCIP) classification: part 2. Initial validation using vignettes. Spinal Cord. 2012;50(6):404-12. doi:10.1038/sc.2012.2

41. Cervero F. Visceral pain-central sensitisation. Gut. 2000;47(Supp 4):iv56doi:10.1136/gut.47.suppl_4.iv56

42. Diatchenko L, Nackley AG, Slade GD, Fillingim RB, Maixner W. Idiopathic pain disorders-pathways of vulnerability. Pain. 2006;123(3):226-30. doi:10.1016/j. pain.2006.04.015

43. Diatchenko L, Slade GD, Nackley AG, et al. Genetic basis for individual variations in pain perception and the development of a chronic pain condition. Hum Mol Genet. 2005;14(1):135-43. doi:10.1093/hmg/ddi013

44. Finnerup NB, Scholz J, Attal N, et al. Neuropathic pain needs systematic classification. Eur J Pain. 2013;17(7):953-56. doi:10.1002/j.1532-2149.2012.00282.x

45. Fishman S, Ballantyne J, Rathmell JP. Bonica's Management of Pain, 4th Edition. Lippincott Williams \& Wilkins; 2010.
46. Graven-Nielsen T, Wodehouse T, Langford RM, Arendt-Nielsen L, Kidd BL. Normalization of widespread hyperesthesia and facilitated spatial summation of deep-tissue pain in knee osteoarthritis patients after knee replacement. Arthritis Rheum. 2012;64(9):2907-16. doi:10.1002/ art.34466

47. Harden RN, Bruehl S, Perez RSGM, et al. Validation of proposed diagnostic criteria (the "Budapest criteria") for complex regional pain syndrome. Pain. 2010;150(2):268-74. doi:10.1016/j. pain.2010.04.030

48. Hart OR, Uden RM, McMullan JE, Ritchie MS, Williams TD, Smith BH. A study of national health service management of chronic osteoarthritis and low back pain. Prim Health Care Res Dev. 2015;16(2):157-66. doi:10.1017/ S1463423614000140

49. Jensen TS, Baron R, Haanpää M, et al. A new definition of neuropathic pain. Pain. 2011;152(10):2204-05. doi:10.1016/j. pain.2011.06.017

50. Jensen MP, Chodroff MJ, Dworkin RH. The impact of neuropathic pain on health-related quality of life: review and implications. Neurology. 2007;68(15):1178-82. doi:10.1212/01. wnl.0000259085.61898.9e

51. Knowles CH, Aziz Q. Basic and clinical aspects of gastrointestinal pain. Pain. 2009;141(3):191-209. doi:10.1016/j. pain.2008.12.011

52. Kosek E, Ordeberg G. Abnormalities of somatosensory perception in patients with painful osteoarthritis normalize following successful treatment. Eur J Pain. 2000;4(3):229-38. doi:10.1053/ eujp.2000.0175

53. Kumar SP, Saha S. Mechanismbased classification of pain for physical therapy management in palliative care: a clinical commentary. Indian J Palliat Care. 2011;17(1):80-86. doi:10.4103/0973-1075.78458 
54. Sandroni P, Benrud-Larson LM, McClelland RL, Low PA. Complex regional pain syndrome type I: incidence and prevalence in Olmsted county, a population-based study. Pain. 2003;103(1-2):199-207. doi:10.1016/ s0304-3959(03)00065-4

55. Juyia RF, Kerr HA. Return to play after liver and spleen trauma. Sports Health. 2014;6(3):239-45. doi:10.1177/1941738114528468

56. CDC file of national drug codes for selected benzodiazepines, muscle relaxants, stimulants, opioid analgesics, and linked oral morphine milligram equivalent conversion factors for opioids, 2019 version. Atlanta, GA: Centers for Disease Control and Prevention; 2020. Available upon request at https:// centersfordiseasecontrol.sharefile.com/ Authentication/Login

57. US National Library of Medicine. Benzodiazepine drug class. dailymed. Accessed November 23, 2020. https://dailymed.nlm.nih.gov/dailymed/search.cfm? query $=$ Benzodiazepines \&searchdb $=$ class \& labeltype $=$ all\&sortby $=$ rel\&audience $=$ profe ssional\&page $=1 \&$ pagesize $=200$
58. Quan H, Sundararajan V, Halfon $\mathrm{P}$, et al. Coding algorithms for defining comorbidities in ICD-9-CM and ICD-10 administrative data. Med Care. 2005;43(11):1130-39. doi:10.1097/01. mlr.0000182534.19832.83

59. Goodman DC, Mick SS, Bott D, et al. Primary care service areas: a new tool for the evaluation of primary care services. Health Serv Res. 2003;38(1 Pt 1):287-309. doi:10.1111/1475-6773.00116

60. Wennberg JE, Cooper MM, Bubolz TA, et al. The Dartmouth atlas of health care 1996. American Hospital Publishing. 15-20.

61. US Department of Agriculture. Documentation: 2010 rural-urban commuting area (RUCA) Codes. Economic Research Service. Published 2012. Updated August 17, 2020. Accessed October 29, 2020. https://www. ers.usda.gov/data-products/ruralurban-commuting-area-codes/ documentation/

62. Hellevik O. Linear versus logistic regression when the dependent variable is a dichotomy. Qual Quant. 2009;43(1):5974. doi:10.1007/s11135-007-9077-3

63. Long JS. Regression Models for Categorical and Limited Dependent Variables. 1st ed. SAGE Publications, Inc; 1997.
64. DbVis Software AB. DbVisualizer: the universal database tool. dbvis.com. Accessed October 29, 2020. https://www. dbvis.com/

65. Stata. Stata 14. Accessed October 29, 2020. https://www.stata.com/stata14/

66. Holm S. A simple sequentially rejective multiple test procedure. Scand J Stat. 1979;6(2):65-70.

67. Hartung DM, Kim H, Ahmed SM, et al. Effect of a high dosage opioid prior authorization policy on prescription opioid use, misuse, and overdose outcomes. Subst Abuse. 2018;39(2):239-46. doi:10.1080/0889 7077.2017.1389798

68. Wolf SJ, Byyny R, Carpenter CR, et al. Clinical policy: critical issues related to opioids in adult patients presenting to the emergency department. Ann Emerg Med. 2020;76(3):13-39. doi:10.1016/j. annemergmed.2020.06.049

69. Cantrill SV, Brown MD, Carlisle RJ, et al. Clinical policy: critical issues in the prescribing of opioids for adult patients in the emergency department. Ann Emerg Med. 2012;60(4):499-525. doi:10.1016/j. annemergmed.2012.06.013 